\title{
Nested-PCR for the detection of Mycoplasma hyopneumoniae in bronchial alveolar swabs, frozen tissues and formalin-fixed paraffin-embedded swine lung samples: Comparative evaluation with immunohistochemical findings and histological features ${ }^{1}$
}

\author{
Paula R. Almeida², Caroline P. Andrade², Laura L. Almeida², Luiz G.S. Oliveira², \\ Luiza A. Castro ${ }^{2}$, Priscila Zlotowski ${ }^{2}$, Sérgio C. da Silva ${ }^{2}$ and David Driemeier ${ }^{2 *}$
}

\begin{abstract}
Almeida P.R., Andrade C.P., Almeida L.L., Oliveira L.G.S., Castro L.A., Zlotowski P., Silva S.C. \& Driemeier D. 2012. Nested-PCR for the detection of Mycoplasma hyopneumoniae in bronchial alveolar swabs, frozen tissues and formalin-fixed paraffin-embedded swine lung samples: Comparative evaluation with immunohistochemical findings and histological features. Pesquisa Veterinária Brasileira 32(8):715-720. Setor de Patologia Veterinária, Faculdade de Veterinária, Universidade Federal do Rio Grande do Sul, Av. Bento Gonçalves 9090, Porto Alegre, RS 91540-000, Brazil. E-mail: davetpat@ufrgs.br.

The diagnosis of Mycoplasma hyopneumoniae infection is often performed through histopathology, immunohistochemistry (IHC) and polymerase chain reaction (PCR) or a combination of these techniques. PCR can be performed on samples using several conservation methods, including swabs, frozen tissue or formalin-fixed and paraffin-embedded (FFPE) tissue. However, the formalin fixation process often inhibits DNA amplification. To evaluate whether M. hyopneumoniae DNA could be recovered from FFPE tissues, 15 lungs with cranioventral consolidation lesions were collected in a slaughterhouse from swine bred in herds with respiratory disease. Bronchial swabs and fresh lung tissue were collected, and a fragment of the corresponding lung section was placed in neutral buffered formalin for 48 hours. A PCR assay was performed to compare FFPE tissue samples with samples that were only refrigerated (bronchial swabs) or frozen (tissue pieces). M. hyopneumoniae was detected by PCR in all 15 samples of the swab and frozen tissue, while it was detected in only 11 of the 15 FFPE samples. Histological features of $M$. hyopneumoniae infection were presented in 11 cases and 7 of these samples stained positive in IHC. Concordance between the histological features and detection results was observed in 13 of the FFPE tissue samples. PCR was the most sensitive technique. Comparison of different sample conservation methods indicated that it is possible to detect M. hyopneumoniae from FFPE tissue. It is important to conduct further research using archived material because the efficiency of PCR could be compromised under these conditions.
\end{abstract}

INDEX TERMS: Mycoplasma hyopneumoniae, swine.

RESUMO.- [Detecção de Mycoplasma hyopneumoniae por PCR em amostras de pulmão suíno fixadas em formalina e associação com achados histológicos e imuno-histoquímicos.] 0 diagnóstico de infecção por Mycoplasma hyopneumoniae é frequentemente realizado através

\footnotetext{
${ }^{1}$ Received on January 30, 2012.

Accepted for publication on April 3, 2012

${ }^{2}$ Departamento de Patologia Clínica Veterinária, Faculdade de Veterinária, Universidade Federal do Rio Grande do Sul (UFRGS), Av. Bento Gonçalves 9090, Porto Alegre, RS 95320-000, Brazil. *Corresponding author: davetpat@ufrgs.br
}

de histopatologia, imuno-histoquímica (IHQ) e reação em cadeia da polimerase (PCR), ou uma combinação dessas técnicas. PCR pode ser realizada a partir de amostras submetidas a vários métodos de conservação, incluindo swa$b s$, tecido refrigerado ou congelado, ou ainda tecido fixado em formalina e embebido em parafina (FFEP). Entretanto, o processo de fixação em formalina pode inibir a amplificação de DNA. Para avaliar se DNA de $M$. hyopneumoniae poderia ser recuperado de tecido FFEP, 15 pulmões com lesões de consolidação crânio-ventral de suínos oriundos de rebanhos com problemas respiratórios foram selecionados no abatedouro. Swabs bronquiais e pulmão fresco foram 
colhidos, e um fragmento da mesma porção de pulmão foi colocado por 48 horas em solução de formalina tamponada e posteriormente processado e embebido em parafina. PCR foi realizada comparando amostras de tecido fixado em formalina com amostras que passaram somente por refrigeração (swab bronquial) ou foram congeladas (fragmentos de tecido). A detecção de M. hyopneumoniae ocorreu em todas as 15 amostras de swabs e tecido congelado enquanto em amostras de tecido FFEP, o agente foi detectado somente em 11 das 15 amostras. Características histológicas de infecção por M. hyopneumoniae ocorreram em 11 casos e 7 destas amostras obtiveram marcação imuno-histoquímica positiva. Concordância entre histologia e detecção a partir de tecido FFEP foi observada em 13 casos. Dentre as técnicas analisadas, a PCR foi a mais sensível. A comparação de diferentes métodos de conservação de amostras indica que é possível detectar M. hyopneumoniae a partir de tecido FFEP, fato importante para pesquisa utilizando material arquivado, porém a eficácia do teste de PCR pode ficar comprometida sob essas condições.

TERMOS DE INDEXAÇÃO: Mycoplasma hyopneumoniae, suíno.

\section{INTRODUCTION}

Mycoplasma hyopneumoniae is the main causative agent of pulmonary diseases in pigs and is responsible for large economic losses in the swine industry (Desrosiers 2001, Buddle and O'Hara, 2005, Sibila et al. 2009). Despite its low mortality rate, $M$. hyopneumoniae infections are associated with high morbidity rates. The agents adherence to the cilia of the epithelial cells in the lower airways affects the mucociliary defense mechanism and assists in the entrance of other bacteria, resulting in delayed growth in the affected animals and carcass condemnation at slaughter (Desrosiers 2001, Srinivasan et al. 2002, Martínez et al. 2007, Hansen et al. 2010).

Cranioventral consolidation of the lungs is the most specific macroscopic lesion caused by M. hyopneumoniae (Sarradel et al. 2003, Ribeiro et al. 2004, Redondo et al. 2009). Microscopically, hyperplasia of the bronchus-associated lymphoid tissue (BALT) is the particular feature that is most related to this agent (Sarradel et al. 2003, Redondo et al. 2009). The culture and isolation of M. hyopneumoniae is recognized as the gold standard for the detection of the bacterium because of its high specificity. However, this method is less practical because it requires special Friis medium and because the agent grows slowly. (Thacker 2004, Otagiri et al. 2005). Additionally, other microorganisms that coexist in the sample might outgrow M. hyopneumoniae (Thacker 2004). All these factors make isolation of the organism from field samples even more difficult. Currently, the most frequently used techniques for $M$. hyopneumoniae diagnosis are the histological analysis of affected tissues, immunohistochemistry (IHC) and, more recently, polymerase chain reaction (PCR) (Mattson et al. 1995, Calsamiglia et al. 1999, Ribeiro et al. 2004, Thacker 2004, Otagiri et al. 2005).

Samples used for histological techniques are routinely kept in a $10 \%$ formalin solution and the subsequently embedded in paraffin (formalin-fixed, paraffin-embedded - FFPE)
(Srinivasan et al. 2002, Coura et al. 2005, Delfour et al. 2006, Ferrer et al. 2007), and pathology laboratories keep large collections of FFPE samples, allowing important retrospective studies using histological analysis (Ferrer et al. 2007). However, FFPE samples are not the most appropriate for molecular biology techniques that are dependent on high-quality DNA samples. Formaldehyde causes cross-linking between the nucleic acids and proteins, which not only complicates isolation of the nucleic acids but also introduces polymerase "blocks" during PCR (Gilbert et al. 2007). The purpose of this study was to assess the suitability of FFPE samples for PCR detection of M. hyopneumoniae by comparing refrigerated tissue and swab pulmonary samples with samples that were subjected to formalin fixation and paraffin embedding. These results were also compared to those obtained by IHC and histological evaluation to assess the significance of $M$. hyopneumoniae in terms of chronicity and severity of infection.

\section{MATERIALS AND METHODS}

\section{Sample collection and processing}

Pieces of 15 lung samples were collected from growing-finishing swine at a slaughterhouse. All animals were from seven herds located in the Caí Valley area (Rio Grande do Sul State, Brazil) that had a previous history of respiratory diseases and presented cranioventral lung consolidation. The collected material was divided into two equal fragments per animal. One of the fragments was fixed in a $10 \%$ formalin solution for $48 \mathrm{~h}$, embedded in paraffin and subsequently processed for histological and IHC analysis according to routine procedures in our laboratory (Prophet et al. 1992). The remaining fragment had a bronchial swab collected and was subsequently frozen at $-20^{\circ} \mathrm{C}$. The bronchial swabs were kept refrigerated at $4^{\circ} \mathrm{C}$.

\section{DNA preparation and quantification}

The DNA was extracted from the swabs and frozen tissue samples using a commercial kit (QIAamp DNA mini kit ${ }^{\mathrm{TM}}$ ) according manufacturer instructions. DNA from the formalin fixed paraffin embedded (FFPE) samples was extracted using the QIAamp FFPE tissue $\mathrm{kit}^{\mathrm{TM}}$. Both kits can be used interchangeably, the choice being made based on commercial availability.

The purified DNA was eluted in $100 \mu \mathrm{L}$ of elution buffer. They were quantified in a GeneQuant 1300 spectrophotometer (GE Healthcare). Typically, the purified DNA had an $\mathrm{OD}_{260} / \mathrm{OD}_{280}$ ratio higher than 1.8.

\section{Immunohistochemistry (IHC)}

The tissue samples were sectioned for IHC and hematoxylin-eosin staining (Prophet et al. 1992). Histological and immunohistochemical analysis were performed by the same pathologist. IHC was performed using a hyperimmune antiserum against $\mathrm{Myco}$ plasma hyopneumoniae (kindly provided by Nelson Mores, CNPSA/Embrapa) and diluted to 1:200. For antigenic recovery, the slides were boiled in a pH 6.0 citrate buffer solution for 10 minutes and subsequently incubated with protease XIV for 25 minutes. Next, a Protein Block solution (Dako) was applied for 7 minutes, IHC staining was performed using with AEC chromogen (Dako), and counterstaining was performed using Mayer's hematoxylin.

\section{PCR, amplicon analysis and sequencing}

A nested PCR was used consisting of two nested pairs of oligonucleotides targeting the $16 \mathrm{~S}$ ribosomal region of $M$. hyopneu- 
moniae. The primers used for the amplifications were as follows: MH_Nested_R1_Up ( ${ }^{\prime}$ GAGCCTTCAAGCTTCACCAAGA ${ }^{3}$ ), MH_Nested_R1_Do ( ${ }^{\prime}$ TGTGTTAGTGACTTTTGCCACC $\left.{ }^{3}\right)$, MH_Nested_R2_Up ( ${ }^{5}$ ACTAGATAGGAAATGCTCTAGT $\left.{ }^{3}\right)$ and MH_Nested_R2_Do ( ${ }^{5}$ GTGGACTACCAGGGTATCT $^{3^{\prime}}$ ) (Yamaguti et al. 2008). The primers MH_Nested_R1_Up and MH_Nested_R1_Do were used in the first nested PCR reaction to amplify a 649 bp product. A 352 bp PCR product was subsequently amplified in a second nested PCR using primers MH_Nested_R2_Up and MH_Nested_R2_Do. All PCRs were performed in a $25 \mu \mathrm{L}$ final volume and contained $30 \mathrm{pmol}$ of each primer, $200 \mu \mathrm{M}$ of dNTPs, $1 \mathrm{mM}$ of $\mathrm{MgCl}_{2}$ and $1 \mathrm{U}$ of Platinum $\mathrm{Taq}$ polymerase (Invitrogen). In the first reaction were used $200 \mathrm{ng}$ of DNA template. A second reaction was assembled in a new tube containing a $1 \mu \mathrm{L}$ sample from the first reaction. The DNA extracted from a $M$. hyopneumoniae culture was used as a positive control. Amplifications were performed on a Verity 96well thermocycler (Applied Biosystems). The cycling parameters used for the first nested PCR were $95^{\circ} \mathrm{C}$ for 5 minutes, followed by 30 cycles at $95^{\circ} \mathrm{C}$ for 30 seconds, $60^{\circ} \mathrm{C}$ for 30 seconds and $72^{\circ} \mathrm{C}$ for 45 seconds. The parameters for the second nested PCR were $95^{\circ} \mathrm{C}$ for 5 minutes, followed by 30 cycles of $95^{\circ} \mathrm{C}$ for 30 seconds, $60^{\circ} \mathrm{C}$ for 30 seconds and $72^{\circ} \mathrm{C}$ for 30 seconds. The amplicons were analyzed on $2 \%$ agarose gels stained with BlueGreen loading dye I (LGC Biotecnologia).

Samples with very weak or no amplification were subjected to a new reaction using 10 to 500ng of sample DNA in the first PCR in order evaluate for the presence of potential false negative resulting from inhibition or lack of sensitivity. Additionally, 10 to 500ng of a control DNA were included in selected reactions in order to rule out false negatives. The identity of the PCR products was verified by DNA sequencing. Five random amplicons were selected, purified using PureLink $^{\mathrm{TM}}$ PCR Purification Kit (Invitrogen) and quantified using a Qubit fluorescence quantification system (Invitrogen) according with manufacturer's instructions. Sequencing of the amplicons was carried out using the BigDye Terminator version 3.1 Cycle Sequencing kit in an ABI PRISM 3130 Genetic Analyzer (Applied Biosystems). Each sample was sequenced independently using both forward and reverse primers, until a Phred quality score of at least 20 (Ewing and Green, 1998; Ewing et al. 1998) was obtained for each individual base in the consensus sequence. The resulting chromatograms were analyzed using the Staden package version 1.7.0 programs (Staden et al. 2003).

\section{RESULTS}

BALT hyperplasia (BH) was the most consistently observed histological lesion (Fig.1), which was present in 11 of the 15 samples (Table 1). All but 2 samples presented a multifocal mononuclear perivascular infiltrate (data not shown). A marked BALT hyperplasia was found in 5 of the samples analyzed. Other alterations included the presence of alveolar macrophages (MI), neutrophils in the alveoli (NI) and alveolar edema (AE), with 5 samples presenting simultaneously all of these features (Table 1). Bronchial and bronchiolar epithelial hyperplasia was observed in 4 samples (Fig.2) while 2 other samples stained positive using IHC (Fig.3). The histological evaluation of the bronchiolar epithelium was impaired in sample \#7 due to autolysis. IHC analysis revealed 7 positive samples in the epithelial cells of the bronchus and bronchioles (Fig.2 and 3, Table 1), all of them presenting some degree of BALT hyperplasia. Howe-

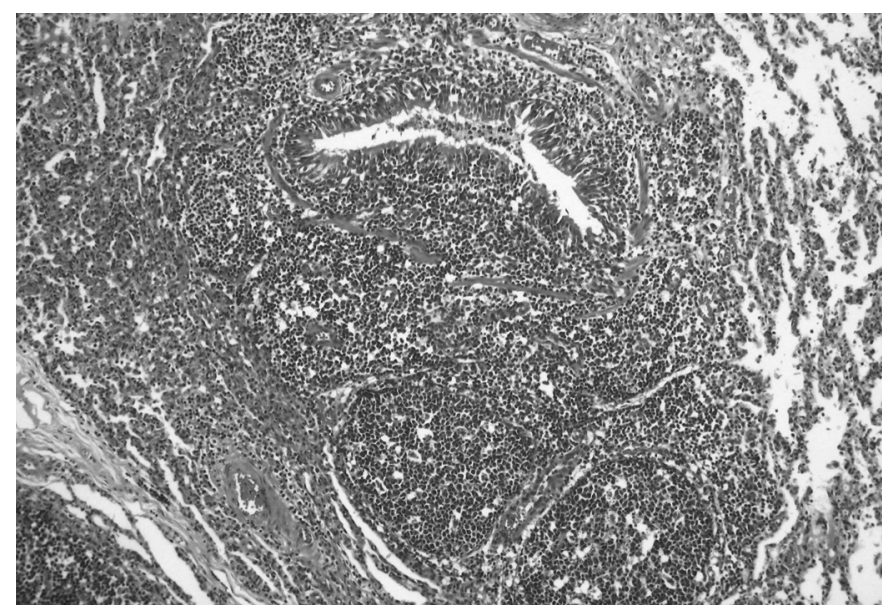

Fig.1. Histological section of a swine lung showing marked BALT hyperplasia, highly indicative of Mycoplasma hyopneumoniae infection. HE, obj.10x.

Table 1. Comparison between results from polymerase chain reaction (PCR), histology and immunohistochemistry (IHC)

\begin{tabular}{|c|c|c|c|c|c|c|c|c|}
\hline \multirow[t]{2}{*}{ Sample } & \multicolumn{3}{|c|}{ PCR } & \multicolumn{4}{|c|}{ Histology } & \multirow[t]{2}{*}{$\mathrm{IHC}^{\mathrm{f}}$} \\
\hline & $\begin{array}{c}\text { Refrigerated } \\
\text { swab }\end{array}$ & $\begin{array}{c}\text { Frozen } \\
\text { tissue }\end{array}$ & $\mathrm{FFPE}^{\mathrm{a}}$ & $\mathrm{BH}^{\mathrm{b}}$ & $\mathrm{MI}^{\mathrm{c}}$ & $\mathrm{NI}^{\mathrm{d}}$ & $A E^{e}$ & \\
\hline 1 & + & + & + & {$[+++]$} & - & + & - & + \\
\hline 10 & + & + & + & {$[+++]$} & - & - & - & + \\
\hline 11 & + & + & + & {$[+++]$} & + & + & + & + \\
\hline 15 & + & + & + & {$[+++]$} & - & - & - & + \\
\hline 9 & + & + & + & {$[+++]$} & - & - & - & - \\
\hline 8 & + & + & + & {$[++]$} & - & - & + & + \\
\hline 13 & + & + & + & {$[++]$} & + & + & + & - \\
\hline 12 & + & + & + & {$[+]$} & + & + & - & + \\
\hline 14 & + & + & + & {$[+]$} & + & + & + & + \\
\hline 3 & + & + & + & {$[+]$} & + & + & + & - \\
\hline 7 & + & + & + & {$[-]$} & - & - & - & - \\
\hline 5 & + & + & - & {$[+]$} & + & - & + & - \\
\hline 2 & + & + & - & {$[-]$} & - & - & - & - \\
\hline 4 & + & + & - & {$[-]$} & + & + & + & - \\
\hline 6 & + & + & - & {$[-]$} & - & - & - & - \\
\hline
\end{tabular}

$\bar{a}$ Formalin-fixed, paraffin embedded; ${ }^{\mathrm{b}}$ BALT (bronchus-associated lymphoid tissue) hyperplasia: [-] absent, [+] mild, [++] moderate, $[+++]$ marked; ' Macrophage infiltration: - (absent), + (present); ${ }^{\mathrm{d}}$ Neutrophil

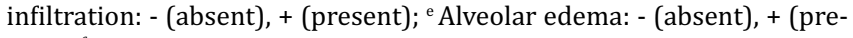

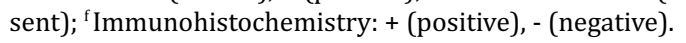

ver, half of the remaining 8 samples that did not stain using IHC presented some degree of BALT hyperplasia under histological evaluation.

Regarding the PCR results, it was possible to amplify Mycoplasma hyopneumoniae DNA from all 15 swabs and frozen tissue samples. However, in 4 of the FFPE samples it was not possible to detect any DNA amplification (Table 1). It is worth noting that 3 of the FFPE samples where no amplification could be detected did not present BALT hyperplasia. All PCR-positive FFPE samples except sample \#7 had histological features compatible with M. hyopneumoniae infection. In 3 samples (\#3, \#9 and \#13), despite its histological features and positive PCR results, the IHC was negative. Agreement between the histological features and PCR detection results was observed in 13 of the FFPE tissue samples. 


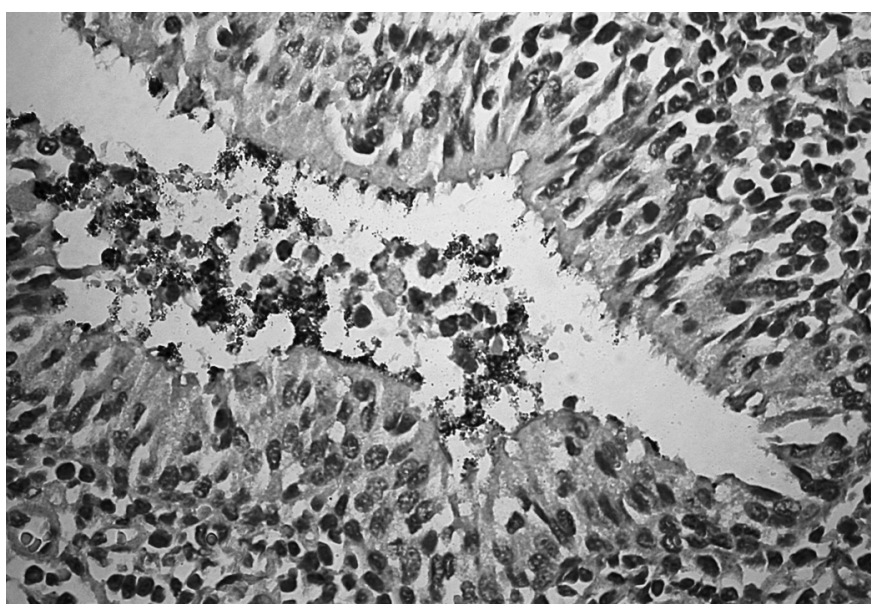

Fig.2. Histological section of a swine lung showing a bronchiole presenting epithelial hyperplasia and the $M$. hyopneumoniae antigen on its surface. AEC and Mayers hematoxylin, obj.40x.

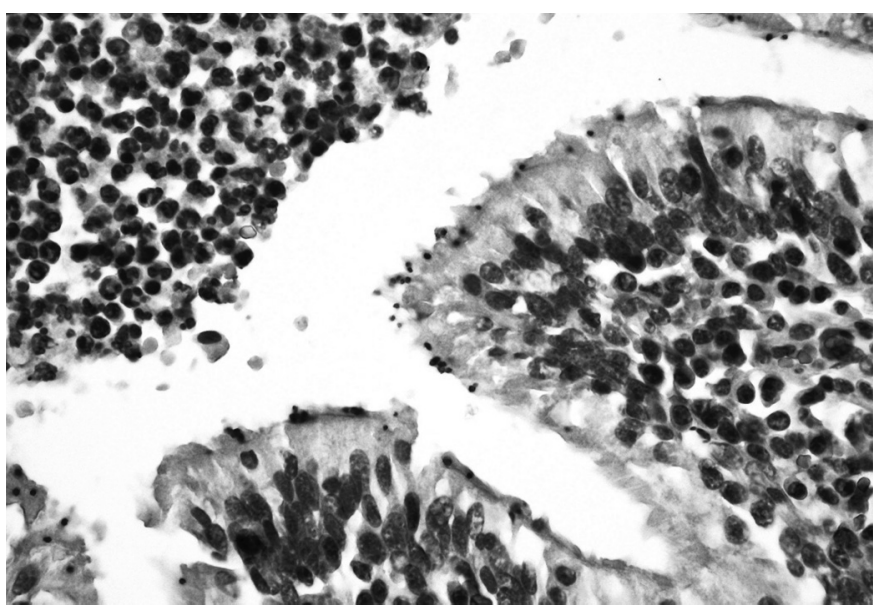

Fig. 3. Histological section of a swine lung showing the Mycoplasma hypneumoniae antigen labeled in the cilia of a bronchiole. AEC and Mayers hematoxylin, obj.40x.

\section{DISCUSSION}

The cranioventral consolidation observed in the lung samples obtained in this study has also been reported in other studies involving Mycoplasma hyopneumoniae (Sarradel et al. 2003, Redondo et al. 2009) and can be attributed to the accumulation of mucus and exudates caused by a loss of mucociliary function, increased production of mucus by the globlet cells, bronchoconstriction caused by chemical mediators released by the alveolar macrophages, and the presence of BALT hyperplasia.

Microscopically, BALT hyperplasia was the most consistent histological feature. Among the histological findings in the swine lungs, BALT hyperplasia is one of the most indicative of M. hyopneumoniae infection (Sarradel et al. 2003, Redondo et al. 2009, Hansen et al. 2010). The presence of macrophages, neutrophils and alveolar edema is commonly associated with secondary bacterial infection (Redondo et al. 2009, Hansen et al. 2010). The presence of neutrophils is also related to the clearance of cellular debris from epithelial exfoliation caused by this agent (Redondo et al. 2009). Epithelial hyperplasia in the bronchus and in the bronchioles was observed in 4 cases with BALT hyperplasia. This characteristic feature results from the adherence of M. hyopneumoniae to the cilia (Hansen et al. 2010). Observation of epithelial hyperplasia can be impaired in samples that have some degree of autolysis, which was the case with sample \#7.

We observed a good correlation between the results from the PCR performed on the FFPE samples and the BALT hyperplasia found in all but two samples (\#7 and \#5). However, a great degree of variability was found in the histopathological lesions, because the animals presenting marked BALT hyperplasia did not present either macrophage or neutrophil infiltration or alveolar edema. Conversely, one animal in which BALT hyperplasia had not been detected presented all the other microscopic lesions. This variability could depend on the infection stage, the age of the animal when the infection took place, the presence of secondary infection and the chronicity of the lesions (Mattson et al. 1995, Calsamiglia et al. 2000).

M. hyopneumoniae could be detected by PCR in all 7 samples that were positive by IHC, which is consistent with the high specificity reported for the IHC in other studies (Opriessnig et al. 2004, Redondo et al. 2009). Interestingly, the IHC staining was marked in the bronchioles that showed BALT hyperplasia. However, the remaining 8 samples that did not stain using IHC were positive by PCR. Four of these samples did not present BALT hyperplasia in the histological analysis. The mycoplasma colonization in the lungs of these animals could have been so recent that detection using IHC was not possible owing to a low cell count. Under these conditions, IHC did not present a high degree of sensitivity.

Our results indicate that $M$. hyopneumoniae detection by PCR is less effective when performed on FFPE samples. The main obstacle to reproducibility of PCR assays on formalin-fixed tissue is the degradation of the DNA, wich is influenced by the time between collection of the tissue and fixation, the fixative used and mostly the duration of fixation (Greer et al. 1991). There are several methods of DNA extraction, and the variables of each step may influence the quality and quantity of DNA extracted (Gilbert et al. 2007). In FFPE tissue, silica-binding based extraction yields a great amount of amplifiable DNA (Bonin et al. 2010). Tissue fixation and the age of embedded tissue are important factors affecting the size of target DNA that can be amplified successfully (Greer et al. 1994).

Fixation causes DNA fragmentation, reducing the probability that lengthy DNA fragments could be amplified (Greer et al. 1991). The duration of storage of paraffin embedded tissues is another factor to consider. While short (270 bp) fragments of the human beta-globin gene could be amplified after storage of paraffin blocks for about 15 years, there was a rapid decline in the success of PCR for fragments greater than 500 bp after 1-2 years (Greer et al.1994). It is well known that formalin interacts with tissues producing excessively small DNA fragments (Weiss et al. 2011). Even short-term treatment of sections with formalin have been shown to significantly reduce the DNA solubility (Srinivasan et al. 2002). 
The formaldehyde initiates DNA denaturation (interchain hydrogen bonds break and bases unstacking) at the AT-rich regions of double-stranded DNA creating sites for chemical interaction (Srinivasan et al. 2002). The Mycoplasma hyopneumoniae genome presents a high $\mathrm{A}+\mathrm{T}$ content of about 70\% (Vasconcelos et al. 2005) thereby the effects of fixatives produce greater damages on its DNA, making its extraction and manipulation a major challenge.

Ha et al. (2005), found a 100\% agreement between seminested PCR on formalin-fixed and fresh lung tissues. However, their study included only 5 samples of experimentally infected pigs and the amplicons were of considerably smaller sizes (281 bp and $184 \mathrm{bp}$ for the first and second reactions, respectively).

Therefore, the effectiveness of PCR amplification from FFPE samples also varies according to the features of the amplification target and differs for each infectious agent and each of its regions. Fresh swabs or frozen tissues remain the best alternatives for sample conservation. The choice of sample conservation method will depend on the laboratory test required, and in the case of PCR, the method may interfere with the results.

The combination of classical histopathology and PCR analysis is an interesting alternative because it could provide information about the stage of the infection, and it also could be used to evaluate the efficacy of vaccination programs. Pathogen detection and analysis by molecular biology methods, including DNA amplification by PCR and DNA sequencing, using archived FFPE samples could be important tools to assess the variability of these agents in archived material; comparison between these methods and histological and IHC analysis allows us to observe changes in the host systemic response over time.

Storage of frozen tissue samples is expensive and time-consuming. For many retrospective studies, formalin-fixed and paraffin-embedded (FFPE) material is, therefore, the only available tissue for DNA analysis (Weiss et al. 2011)

The ability to amplify Mycoplasma hyopneumoniae DNA from formalin-fixed, paraffin-embedded tissue allows the assay to be performed in conjuction with the examination of tissue for characteristic histopathologival changes. Thus this assay should be a valuable confirmatory diagnostic tool.

This method also offers the advantage of using routine formalin-fixed, paraffin-embedded histological specimens in retrospective study, obviating the need for frozen or fresh materials. The development of such technique is most pertinent as formalin fixation of tissues allows veterinary practitioners to ship tissue samples for $M$. hyopneumoniae identification in a well-preserved, non-infectious state.

Acknowledgements.- To our colleagues at the SPV/LBMA-UFRGS for their technical support and to FAPERGS, CAPES and CNPq for financial support.

\section{REFERENCES}

Bonin S., Hlubek F., Benhattar J., Denkert C., Dietel M., Fernandez P.L., Höfler G., Kothmaier H., Kruslin B., Mazzanti C.M., Perren A., Popper H., Scarpa A., Soares P., Stanta G. \& Groenen P.J.T.A. 2010. Multicentre validation study of nucleic acids extractionfrom FFPE tissues. Virchows Arch. 457: 309-317.
Buddle J.R. \& O'Hara A.J. 2005. Enzootic pneumonia of pigs: A diagnostic dilemma. Aust. Vet. J. 83(3):134-139.

Calsamiglia M., Collins J.E. \& Pijoan C. 2000. Correlation between the presence of enzootic pneumonia lesions and detection of Mycoplasma hyopneumoniae. Vet. Microbiol. 76:299-303.

Calsamiglia M., Pijoan C. \& Bosch G.J. 1999. Profiling Mycoplasma hyopneumoniae in farms using serology and a nested PCR technique. J. Swine Health Prod. 7:263-268.

Coura R., Prolla J.C., Meurer L. \& Ashton-Prolla P. 2005. An alternative protocol for DNA extraction from formalin fixed and paraffin wax embedded tissue. J. Clin. Pathol. 58(8):894-895.

Delfour C., Roger P., Bret C., Berthe M.L., Rochaix P., Kalfa N., Raynaud P., Bibeau F., Maudelonde T. \& Boulle N. 2006. RCL2, a new fixative, preserves morphology and nucleic acid integrity in paraffin-embedded breast carcinoma and microdissected breast tumor cells. J. Mol. Diagn. 8(2):157-169.

Desrosiers R. 2001. A review of some aspects of the epidemiology, diagnosis and control of Mycoplasma hyopneumoniae infections. J. Swine Health Prod. 9:233-237.

Ewing B. \& Green P. 1998. Basecalling of automated sequencer traces using phred. II. Error probabilities. Gen. Res. 8:186-194.

Ewing B., Hillier L., Wendl M. \& Green P. 1998. Basecalling of automated sequencer traces using phred. I. Accuracy assessment. Gen. Res. 8:175185.

Ferrer I., Armstrong J., Capellari S., Parchi P., Arzberger T., Bell J., Budka H., Ströbel T., Giaccone G., Rossi G., Bogdanovic N., Fakai P., Schmitt A., Riederers P., Al-Sarraj S., Ravid R. \& Kretzschmar H. 2007. Effects of formalin fixation, paraffin embedding, and time of storage on DNA preservation in brain tissue: A BrainNet Europe study. Brain Pathol. 17(3):297-303.

Gilbert M.T., Haselkorn T., Bunce M., Sanchez J.J., Lucas S.B., Jewell L.D., Van Marck E. \& Worobey M. 2007. The isolation of nucleic acids from fixed, paraffin-embedded tissues-which methods are useful when? PLoS One 2(6):e537.

Greer C.E., Lund J.K. \& Manos M. 1991. PCR amplification from paraffin-embedded tissues: Recommendations on fixatives for long-term storage and prospective studies. Gen. Res. 1:46-50.

Geer C.E., Wheeler C.M. \& Manos M. 1994. Sample preparation and PCR amplification from paraffin-embedded tissues. Gen. Res. 3:S113-S122.

Ha S.K., Choi C., Kim O., Song H.C., Lim E.S., Kim S.H., Hwang K.K. \& Chae C. 2005. Development of nested polymerase chain reaction for the detection of Mycoplasma hyopneumoniae in formalin-fixed paraffin-embedded lung tissue. Aust. Vet. J. 83(7): 442-444.

Hansen M.S., Pors S.E., Jensen H.E., Bille-Hansen V., Bisgaard M., Flachs E.M. \& Nielsen O.L. 2010. An investigation of the pathology and pathogens associated with porcine respiratory disease complex in Denmark. J. Comp. Pathol. 143(2/3):120-131.

Martínez J., Jaro P.J., Audriz G., Gómez E.A., Peris B. \& Corpa J.M. 2007. Carcass condemnation causes of growth retarded pigs at slaughter. Vet. J. 174(1):160-164.

Mattson J.G., Bergström K., Wallgren P. \& Johansson K.E. 1995. Detection of Mycoplasma hyopneumoniae in nose swabs from pigs by in vitro amplification of the 16S rRNA gene. J. Clin. Microbiol. 33(4):893-897.

Opriessnig T., Thacker E.L., Yu S., Fenaux M., Meng X.J. \& Halbour P.G. 2004. Experimental reproduction of postweaning multisystemic wasting syndrome in pigs by dual infection with Mycoplasma hyopneumoniae and porcine circovirus type 2. Vet. Pathol. 41(6):624-640.

Otagiri Y., Asai T., Okada M., Uto T., Yazawa S., Hirai H., Shibata I. \& Sato S. 2005. Detection of Mycoplasma hyopneumoniae in lung and nasal swab samples from pigs by nested PCR and culture methods. J. Vet. Med. Sci. 67(8):801-805.

Prophet E.B., Mills B., Arrington J.B. \& Sobin L.H. 1992. Laboratory Methods in Histotechnology. American Registry of Pathology, Armed Forces Institute of Pathology, Washington, DC. 279p.

Redondo E., Masot A.J., Fernández A. \& Gázquez A. 2009. Histopathological and immunohistochemical findings in the lungs of pigs infected with $M y$ coplasma hyopneumoniae. J. Comp. Pathol. 140(4):260-270. 
Ribeiro F.C., Silva J.C.P., Santos J.L. \& Pontes K.C.S. 2004. Diagnóstico da pneumonia enzoótica suína pela técnica da imunoperoxidase. Arq. Bras. Med. Vet. Zootec. 56(6):709-714.

Sarradel J., Andrada M., Ramírez A.S., Fernández A., Gómez-Villamandos J.C., Jover A., Lorenzo H., Herráez P. \& Rodríguez F. 2003. A morphologic and immunohistochemichal study of the bronchus-associated limphoid tissue of pigs naturally infected with Mycoplasma hyopneumoniae. Vet. Pathol. 40(4):395-404.

Sibila M., Pieters M., Molitor T., Maes D., Haesebrouck F. \& Segalés J. 2009. Current perspectives on the diagnosis and epidemiology of Mycoplasma hyopneumoniae infection. Vet. J. 181(3):221-231.

Srinivasan M., Sedmak D. \& Jewel S. 2002. Effect of fixatives and tissue processing on the content integrity of nucleic acids. Am. J. Pathol. 161(6):1961-1971.

Staden R., Judge D.P. \& Bonfield J.K. 2003. Managing Sequencing Projects in the GAP4 Environment. Introduction to Bioinformatics: A theoretical and practical approach, p.327-344. In: Krawetz S.A. \& Womble D.D. (Eds), Human Press Inc., Totawa, NJ 07512.

Thacker E.L. 2004. Diagnosis of Mycoplasma hyopneumoniae. Anim. Health Res. Rev. 5(2):317-320.

Vasconcelos A.T., Ferreira H.B., Bizarro C.V., Bonatto S.L., Carvalho M.O., Pinto P.M., Almeida D.F., Almeida L.G., Almeida R., Alves-Filho L., Assun- ção E.N., Azevedo V.A., Bogo M.R., Brigido M.M., Brocchi M., Burity H.A., Camargo A.A., Camargo S.S., Carepo M.S., Carraro D.M., de Mattos Cascardo J.C., Castro L.A., Cavalcanti G., Chemale G., Collevatti R.G., Cunha C.W., Dallagiovanna B., Dambrós B.P., Dellagostin O.A., Falcão C., Fantinatti-Garboggini F., Felipe M.S., Fiorentin L., Franco G.R., Freitas N.S., Frías D., Grangeiro T.B., Grisard E.C., Guimarães C.T., Hungria M., Jardim S.N., Krieger M.A., Laurino J.P., Lima L.F., Lopes M.I., Loreto E.L., Madeira H.M., Manfio G.P., Maranhão A.Q., Martinkovics C.T., Medeiros S.R., Moreira M.A., Neiva M., Ramalho-Neto C.E., Nicolás M.F., Oliveira S.C., Paixão R.F., Pedrosa F.O., Pena S.D., Pereira M., Pereira-Ferrari L., Piffer I., Pinto L.S., Potrich D.P., Salim A.C., Santos F.R., Schmitt R., Schneider M.P., Schrank A., Schrank I.S., Schuck A.F., Seuanez H.N., Silva D.W., Silva R., Silva S.C., Soares C.M., Souza K.R., Souza R.C., Staats C.C., Steffens M.B., Teixeira S.M., Urmenyi T.P., Vainstein M.H., Zuccherato L.W., Simpson A.J. \& Zaha A. 2005. Swine and poultry pathogens: The complete genome sequences of two strains of Mycoplasma hyopneumoniae and a strain of Mycoplasma synoviae. J. Bacteriol. 187(16):5568-5577.

Weiss A.T.A., Delcour N.M., Meyer A. \& Klopfleisch R. 2011. Efficient and cost-effective extraction of genomic DNA from formalin-fixed and paraffin-embedded tissues. Vet. Pathol. 48(4):834-838.

Yamaguti M., Muller E.E., Piffer A.I., Kich J.D., Klein C.S. \& Kuchiishi S.S. 2008. Detection of Mycoplasma hyopneumoniae by polymerase chain reaction in swine presenting respiratory problems. Braz. J. Microbiol. 39:471-476. 